\title{
Unknown if New Disease is Multifocal
}

National Cancer Institute

\section{Source}

National Cancer Institute. Unknown if New Disease is Multifocal. NCI Thesaurus. Code C160683.

It is unknown if the new disease is multifocal. 